\title{
Delineation of Catastrophic Effects of Climate Modifications in Pakistan Using GIS and Remote Sensing
}

\author{
Hafsa Bashir, Shiekh Saeed Ahmad" \\ Department of Environmental Sciences, Fatima Jinnah Women University, Pakistan
}

Copyright $\subset 2017$ by authors, all rights reserved. Authors agree that this article remains permanently open access under the terms of the Creative Commons Attribution License 4.0 International License

\begin{abstract}
With the increased urbanization, the phenomenon of global climatic modification is observed. The global climate change has more effects over developing countries like Pakistan. The change in climate varies over time scale as well as from country to country and region to region. The changing scenario has increased the risk of deforestations, changes in crop production yield, glacier melting's, temperature fluctuations and unexpected increase or decrease in river catchments. This review paper will give a brief view about the climatic modification and hazards that were observed as a result of it in Pakistan.
\end{abstract}

Keywords Climate Modifications, GIS \& RS

\section{Introduction}

Climate change refers to general shifts in climate, including temperature, precipitation, winds, and other factors [1]. Due to increased urbanization, fuel burning and carbon dioxide emissions, world's climate is changing rapidly [2].As a result of it, world's temperature had risen up to $0.74^{\circ} \mathrm{C}$ and would be about to increase from $1.8^{\circ} \mathrm{C}$ to $4^{\circ} \mathrm{C}$ by 2100 [3]. The climate modifications varies over different region and country varying over time scale [4].The increase that occur over time scale determines the changes across the globe[5]. Climate modification/change was identified as the most catastrophic issue which had more severely affected developing countries like Pakistan. The major impacts that were highlighted include melting of Himalaya glaciers, subsequent increase in flooding, increased pressure over natural resources and resulting stress over the environment, disease outbreak, impacts on soil fertility, which would end up in erosion and reduced crop growth, this will correspondingly impact the economy and would be a cause of poverty [6]. In Pakistan, apart from natural catastrophes, human induced changes are also playing important role [7]. Unexpected or sudden increase in temperature of Pakistan causes increases sternness level which poses more threat towards life [8].

\section{Losses of Forest Cover in Chakwal Due to Climate Modification}

The climate change activity had caused a loss of around $\$ 3.57$ billion over the past 18 years. As a result of it, the risks of sea level rise, glacial retreat, floods, temperature extremes and intensified droughts had increased. Almost 23\% of the country's land and $50 \%$ of the entire population was found to be vulnerable to these damages. Chakwal is a barani district with naturally existing forest which covered 92382 acres of the district under reserve forest and 57868 acres were under unclassed forest. The prime forest areas in district Chakwal were identified for the study by integrating the areas of land cover change derived for the change in climate in the years 2005-6 and 2009-10 by the use of GIS mapping. For this purpose, ArcGis software was used. Shape file was created following the georeferencing of map. Then the map was digitized and potential areas were marked for the selected years, GPS was used for recording geographical coordinates. Results had shown that the minimum temperature of the district was increased from $9.4^{\circ} \mathrm{C}$ to $9.9^{\circ} \mathrm{C}$ during the period of 2005-06 to 2009-10, and the maximum temperature was increased from $33.8^{\circ} \mathrm{C}$ to $35^{\circ} \mathrm{C}$. The humidity was changed from $69.1 \%$ to $70.3 \%$ followed by the rainfall decrease from $872 \mathrm{~mm}$ to $557 \mathrm{~mm}$. The total forest area was found to be around $698 \mathrm{Km}^{2}$ in the year $2005-06$, but the decline was recorded to about $625 \mathrm{Km}^{2}$ in $2009-10$. These notable changes in the climate caused the decline in the forest area of the region [9].

\section{Temperature Modeling of Indus Basin Using Landsat Data}

The Land surface temperature was found to be important variable that had an effect over surface physical possessions 
and climate which in turn had effect on various environmental processes. The temperature modulations were studied along the Indus basin using Landsat data. The Landsat TM (Thematic Mapper) image, dated 16th May 1992, 15th May 2003 and 15th May 2009 were used effectively for identification of the spatial distribution characteristics of surface temperature of Indus basin. Band 6 of TM respectively were analyzed for the determination of the surface temperatures, images were compared with each other for understanding the relationship between the land cover types and different types of temperature in the Indus basin. Temperature Model was developed in the ERDAS Imagine for the calculation of the surface temperature. When ERDAS imagine processing has completed, finally the images open in Arc Map software and color ramp scheme were applied, reflecting water bodies low temperature, dry land/barren land in high temperature the image; Temperature values image were shown in Kelvin. The Indus basin was divided into four groups because of its lager length and change in temperature after every $100 \mathrm{~km}$. The four regions included first region from Guddu to Sukkur, second region from Sukkur to Nawabshah, third region from Nawabshah to Kotri and the fourth region was from Kotri barrage to Arabian Sea. The analysis of surface temperature using thermal infrared band 6 had revealed that surface temperature was increased from $38.76^{\circ} \mathrm{C}$ in 1992 to $43.1^{\circ} \mathrm{C}$ in 2003.It was found that mean increase of temperature about $4.83^{\circ} \mathrm{C}$ was occurred due to deforestation and anthropogenic activities [10].

\section{Runoff Sensitivity in Upper Indus Basin to Inter-annual Climate Variability}

Upper Indus basin covered an area of about $200,000 \mathrm{~km}^{2}$ and had important role in food security and energy supply. In order to determine the relationship between local climatic observations and regional hydrological responses in upper Indus basin MODIS was used. Snow Covered Area (SCA) and Land Surface Temperature (LST) were used for studying precipitation and sir temperature and were used as an indicator of inputs of energy and mass to melt water generation processes contributing the bulk of runoff in the Upper Indus basin Parametric and non-parametric trend tests were done and then their correlation was found with SCA and LST. It was found that snow covered area was decreased with increasing LST which showed its negative correlation with air temperature. The decreased snow covered area due to increased LST was shown to be resulting increase runoff in summer seasons but decreasing runoff in winters. It was found that change in runoff in summer may vary from -30 to $+35 \%$ or more depending upon the current regional climatic conditions [11].

\section{Cloud Fraction Climatology of the Upper Indus Basin Its Implications for Near-surface Air Temperature}

Clouds play a key role in hydroclimatological variability by modulating the surface energy balance and air temperature. The study utilized MODIS cloud cover data along with global meteorological reanalysis (ERA-Interim) cloud estimates in order to describe cloud climatology for the upper Indus River basin. It had specific focus on tributary catchments in the northwest of the region which had major contribution in larger fraction of basin annual runoff, including $65 \%$ of flow originating above Besham, Pakistan or $50 \mathrm{~km}^{3} \mathrm{yr}^{-1}$ in absolute terms. In this region, substantial cloud cover was recorded throughout the year, with spatial means of $50 \%-80 \%$ depending on the season. The annual cycles of catchment spatial mean daytime and nighttime cloud cover fraction were very similar this regional diurnal homogeneity belied substantial spatial variability, particularly along seasonally varying vertical profiles (based on surface elevation). The estimation of correlations between local near-surface air temperature observations and MODIS cloud cover fraction confirmed the strong linkages between local atmospheric conditions and near-surface climate variability. These correlations were interpreted in terms of seasonal and diurnal variations in apparent cloud radiative effect and its influence on near-surface air temperature in the region. The potential role of cloud radiative effect in recognized seasonally and diurnally asymmetrical temperature trends over recent decades was also assessed by relating these locally observed trends to ERA-Interim-derived trends in cloud cover fraction. The results revealed that reduction in nighttime cloud cover fraction as compared to daytime conditions might be due to more short wave radiation than long wave radiation which had provided a plausible physical mechanism for the observed nighttime cooling of surface air temperature in summer months [12].

\section{Glacial Lake Outburst in Bagrot Valley Due to Climate Change}

The Bagrot valley lays in Karakoram Range was most suspected to flood outbursts due to glacial retreats. Glacial Lake Inventory was developed for Bagrot Valley using GIS/RS .For this purpose, Google earth was used for the identification of lakes on the glaciers. After that, Digital Elevation Model was used for mapping of identified lakes. Regression Analysis was used to study the impact of monthly temperature and precipitation on glacial outbursts. It was found that mean temperature was increased about $0.18{ }^{\circ} \mathrm{C}$ from 1999-2003 and variation in precipitation patterns had altered snow melting trends which had increased the risk of Glacial Lake Outburst Floods (GLOFs). These GLOFs had triggered the catastrophic effects to downstream 
infrastructure and communities [13].

\section{Conifer Forest Decline Mapping}

Conifer forests of Pakistan were mapped using GIS for assessing the impact of climate change from 1990 to 2010 . Thematic maps were prepared using ARCGIS 9.2 from which area of study was extracted. It was found that conifer forest was reduced at rate of $2.3 \%$ every year. Northern areas (Gilgit, Baltistan) and KPK reported the highest annual rates of deforestation (about 34,000 hectares in Northern Areas and 8000 hectares in KPK). The avg. temperature for these areas was raised from $27.67^{\circ} \mathrm{C}$ and $27.4^{\circ} \mathrm{C}$ in 1990 to $28^{\circ} \mathrm{C}$ and $28.5^{\circ} \mathrm{C}$ in 2009 while in northern areas it was reported to be reduced from $24.9^{\circ} \mathrm{C}$ to $23.9^{\circ} \mathrm{C}$. Temperature was a key determinant for the growth of conifer forest in Pakistan. Avg. rainfall, another important factor showed decrease from $269.5 \mathrm{~mm}$ to $210.9 \mathrm{~mm}$ in KPK (1990-2009), $1830.2 \mathrm{~mm}$ to $1152.7 \mathrm{~mm}$ in AJK while it reported to be increased in Northern areas from $89.3 \mathrm{~mm}$ (1990) to $141.1 \mathrm{~mm}$ (2009) [14]

\section{Effect of Temperature Change on Wheat Productivity}

Changing climate had strong impact over agricultural production. Rainfed areas of Pakistan such as Pothwar were major victims of it. DSSAT model was applied for assessing impact of climate change over wheat fields. Spatial maps were generated which showed rise in maximum and minimum temperature reduced the wheat yields of the Pothwar region of Pakistan [15].

\section{Climate Change Impact over Rice Yield}

Pakistan, being the rich rice producer, was severely affected by climate change. Thematic maps were produced and area of interest was extracted. ARCGIS was used for integration of spatial as well as attribute data. Choropleth maps were generated using ARCGIS 9.2 for the years of 1989 to 2009 which was further correlated with climatic data. It was reported that rice production was increased all over Pakistan but in 2000, when Pakistan faced severe drought it was decreased [16].

\section{Conclusions}

Certain degree rise in temperature in Pakistan is posing severe threats over Pakistan's climatic conditions. Changes in weather patterns are responsible for flash floods, glacier retreats, and sudden increase in Indus River which is affecting the hydrological activity of river. Increase in temperature is also responsible for GHG'S emission as forest cover of Pakistan is decreasing as a result of it temperature is rising. Inter- annual temperature is rising in Indus which is increasing run-off in upper Indus basin.

\section{REFERENCES}

[1] S. Khalil, S. Zaheer. Climate change and relationship between meteorological parameters: A case study of Jaccobabad (Sind) Pakistan. International Journal of Asian Social Science, Vol. 3, No. 7, 1607-1624, 2013

[2] Anonymous. IPCC (Intergovernmental Panel on Climate Change). Climate change 2007: the physical science basis. Geneva, Switzerland, 2007

[3] Anonymous. District Gazetteer of Chakwal 2010. Divisional Forest Office, Rawalpindi, 2010

[4] J.R. O'Connor, P.A. Roelle, V.P. Aneja. An ozone climatology: Relationship between meteorology and ozone in the southeast USA. International Journal of Environment and Pollution, Vol. 2, No 2, 123 - 139, 2005.

[5] Back, L.E. and Bretherton, C.S. The relationship between wind speed and percipitation in the pacific Itcz, Department of atmospheric sciences University of Washington, Seattle: WA. J. Climate, 2004

[6] K.M. Siddiqui, I. Mohammad, M. Ayaz. Forest ecosystem climate change impact assessment and adaptation strategies for Pakistan. Climate Research, Vol. 12, 195-203,1999

[7] S.S. Ahmad, A. Sherazi, M.T.A. Shah. A preliminary study on climate change causing decline in forest cover area in district Chakwal, Pakistan. Pakistan Journal of Botany, Vol 42, No.6,3967-3970, 2010

[8] A. Farooqi, A.H. Khan, M. Hazrat. Climate change perspective in Pakistan. Pakistan Journal of Meteorology, Vol. 2, No. 3, 11-21, 2005

[9] J. Shukla, B. M. Misra. Relationships between sea surface temperature and wind speed over the central Arabian Sea, and moonsoon rainfall over India, Massachusetts institute of technology, Cambridge 02139, Monthly Weather Review, Vol. 105, No. 8, 998-1002, 1976

[10] Abbasi, H.U., Soomro, A.S., Memon, A., Samo, S.R., and Karas, I.R. Temperature Modeling of Indus Basin Using Landsat Data. Sindh University Research Journal (Science Series), Vol. 44 , No. 2, 177-182, 2012

[11] N. Forsythe, C.G. Kilsby, H.J. Fowler, D.R. Archer. Assessment of Runoff Sensitivity in the Upper Indus Basin to Interannual Climate Variability and Potential Change Using MODIS Satellite Data Products. Mountain research and development, Vol. 32, No. 1, 16-29, 2012

[12] N. Forsythe, A.J. Hardy, H.J. Fowler, S. Blenkinsop, C.G. Kilsby, D.R. Archer, M.Z. Hashmi. A Detailed Cloud Fraction Climatology of the Upper Indus Basin and Its Implications for Near-Surface Air Temperature. Journal of Climate, Vol. 28, 3537-3556, 2015 
[13] D. Hussain, M. Raza, G. Rasul, M. Ismail. Glacial Lake outburst flooding in Bagrot valley- new thread due to climate change. Journal of Biodiversity and Environmental Sciences, Vol. 6, No.3,207-212, 2015

[14] S.S. Ahmad, Q. Abbasi, R. Jabeen, M.T. Shah. Decline of Conifer forest cover in Pakistan: A GIS approach. Pakistan Journal of Botany, Vol. 44, No. 2, 511-514, 2012.
[15] M. Jabeen, H.F. Gibrael, M. Ahmad, M.A. Mahboob, J, Iqbal. Studying Impact of Climate Change on Wheat Yield by Using DSSAT and GIS: A Case Study of Pothwar Region. Springer, 387-411, 2016.

[16] N. Fatima, R. Shabbir. Temporal Analysis of Rice Yield and Climatic Trends in Pakistan. World Applied Sciences Journal, Vol. 24, No. 10, 1330-1338, 2013 